ROCZNIKI KULTUROZNAWCZE

Tom/Vol. XI, numer/number 3 - 2020

DOI: http://dx.doi.org/10.18290/rkult20113-1

CARD. GIANFRANCO RAVASI

\title{
FAITH AND CULTURE IN THE TIME OF CORONAVIRUS
}

The social experience of Covid-19 has already generated in many countries an impressive bibliography of multiple genres and in many fields. It is tempting to oppose this excess of analysis and reflection with the voice of Job. He rejected the words of his theological friends who came to comfort him by calling them "sap of the mallow," unable to extinguish his lacerating pain. Or, we might be inclined to resound the harsh phrase of another biblical sage, Qoheleth, who warned: "All things are wearisome, more than words can say" (1:8).

Yet all communities live through events that can generate new cultural, religious, social, and, more specifically, anthropological phenomena and models. But perhaps there is a lack of great intellectual figures capable of extracting a symbolic banner from lived reality. To make this observation more explicit it would be sufficient to refer to the memorable pages of Alessandro Manzoni's The Betrothed (1827) where he re-elaborates the plague that struck Italy in the years 1629-31. Or we could resort to that dramatic masterpiece from Albert Camus, his famous novel The Plague (1947), especially for the problem of theodicy that it proposes following Dostoevsky's Brothers Karamazov. Or we could even evoke the lesser known but suggestive Letters from a City in Mourning (1885) by the Swedish doctor and writer Axel Munthe, who journeyed to Naples in 1884 to cure the victims of a cholera epidemic.

On a religious level, however, a high-level presence has been manifested: the images seen around the world of Pope Francis in an empty St. Peter's Square, under the pouring rain with the emblem of the crucified Christ. The

Card. Gianfranco Ravasi - President of the Pontifical Council for Culture; e-mail: cultura@cultura.va. 
thoughtful Gospel words shared through the storm that night on 27 March, were and will be the admirable synthesis of a great human and spiritual approach to the pandemic. Pope Francis, on several occasions, has brought the event back to the very heart of Christianity. In fact, the Christian God is different from ancient divinities like Jupiter, who were relegated to their golden Olympic world, apathetic to human suffering. Ours, instead, is a God who in the Incarnation has chosen to assume the same human experience as each one of us, made of joy, certainly, but also of limit, pain and death.

Christ too was afraid and even horrified by death, whose stern face appeared before him as it appears before us now, even though we had previously exorcised and ignored it: "Father, if it is possible, take this poisoned chalice away from me." $\mathrm{He}$, too, experienced isolation from his friends: the disciples remained far away, they abandoned him, as occurs to many sick lonely people. He too had his flesh wounded by torture and experienced even the worst of loneliness, the silence of the Father ("My God, my God, why have you abandoned me?").

In the end, because of the crucifixion, he too died like many coronavirus patients, from asphyxia, after taking a last breath. Dietrich Bonhoeffer, the theologian martyr of Nazism, was right when he wrote in his prison diary: "God in Christ does not save us by virtue of his omnipotence, but by virtue of his impotence." Yes, because in those moments he did not bend over some sick person to heal him or her, as he had done during his earthly life, but he himself became suffering and mortal. He did not free us from evil but was with us in physical and inner evil.

Yet even when he was a corpse tossed here and there, as happened to many victims of the virus during this period, he was still the Son of God. That is why - by experiencing in his flesh our miserable, fragile and mortal humanity - he placed in it forever a seed of eternity and hope destined to blossom forever. This is the meaning of Easter, "the other side of life compared to the side facing us," as the Austrian poet Rainer M. Rilke used to say.

On the general cultural level, this evil has taught many other things to those who believe and also to those who do not. It has, in fact, revealed to us the greatness of science but also its limits; it has rewritten the scale of values that does not have money or power at its summit; staying at home together, fathers and children, young and old, have rediscovered the efforts and joys of relationships that are not just virtual; it has simplified the superfluous and taught us the essential; it has forced us to look into the eyes of our loved ones and see our own death; it has made us brothers and sisters to the many 
Jobs of today, giving us the right even to protest with God, to raise our questions and complaints to him.

But above all it has revealed a supreme value that is inseparably human and religious: love. Many know the novel by the Colombian writer Gabriel García Márquez, Love in the Time of Cholera (1982), a title that could be transcribed for the coronavirus. A title that has been truth especially in the many doctors, nurses, volunteers and various operators who have been ready to go beyond the law of "loving your neighbor as yourself," to follow the extreme law of Jesus: "There is no greater love than those who give their lives for their friends."

Now an uncertain and difficult future unfolds before us, especially on the social and economic levels. Science itself is struggling, looking for a vaccine. The virus in general is, in fact, a surprising chapter for biochemistry itself. No one knows exactly how and when viruses appeared on Earth. Some think that they were born before other forms of life; others claim that they appeared during the development of the first forms of life; still others believe that they are nothing more than a regression of some more evolved forms of life. No one has yet been able to define with certainty whether or not they are living beings. According to the various criteria that define life forms (e.g. metabolism, osmosis, growth), it seems that only one can be applied to viruses: the ability to reproduce.

More precisely, can parasitic replication be enough to define viruses as life forms? Is this really enough to close the debate on what a living life form is compared to a complex cluster of molecules? This is just to touch on one of the many scientific questions that were already open in the past and that have now become more urgent and have a strong impact on the public at large.

In conclusion, we would like to return to the cultural and religious experience. There is a sort of mantra that is also recited by many: "resilience," from the Latin resilire, "bounce," which can be used to define that property of some materials, such as metals, to absorb a shock without breaking, recovering the original form. Translated into the psychological sphere, it can indicate the cognitive, emotional and behavioral processes that re-elaborate pain, loss, grief and trauma, overcoming them and rebuilding our own personal structures and developing inner energies that were previously unknown.

It is, therefore, possible to hope, through the same human capacity for resilience, for the resumption of personal and community life in fullness. This psycho-physical category must, however, also be associated with the 
mission that faith carries out through the theological virtue of hope and the awareness of the primacy of divine grace.

In the Bible the divine greeting "Do not be afraid!" resounds 365 times. It is almost the "good morning" that God repeats at every dawn. It is repeated ideally even in this difficult time. And for those who have lost faith we can suggest, instead, the confession of the writer García Márquez mentioned above: "Unfortunately, God does not have a place in my life. I have hope, if He exists, that I have a place in His." 